\title{
Spectrofluorimetric Determination of Some N. Containing Medicines Using Rhodamine 6G as a Chromogenic Reagent
}

\author{
Mohamed Y. Dhamra and Theia'a N. Al-Sabha* \\ Chemistry Department, College of Education for Pure Science, Mosul University, Mosul, Iraq. \\ *Corresponding Author Email: dr_theiaa@yahoo.co.uk \\ Received 22 April 2021, Revised 04 December 2021, Accepted 16 December 2021
}

\begin{abstract}
A sensitive spectrofluorimetric method has been developed for the analysis of some medicines containing primary, secondary, and tertiary amino groups, namely Diclofenac (DIC), Domperidone (DOM), Famotidine (FAM), and Propranolol (PRO), in their pure and medicinal forms. The method is based on the quenching of the fluorescence intensity of rhodamine $6 \mathrm{G}$ (R$6 \mathrm{G})$ through the formation of ion-pair complexes between the above medicines and the R-6G reagent, which is measured at $552 \mathrm{~nm}$ after excitation at $402 \mathrm{~nm}$. The calibration graphs were rectilinear in the concentration ranges of $0.10-9.00,0.05-15.00,0.10-14.0$ and $0.05-5.00 \mu \mathrm{g} \mathrm{mL}^{-1}$ for above medicines respectively. The recovery $(\%)$ values were ranged between $99.45 \%$ $100.97 \%$. The detection limits ranged in the concentration of $0.243-0.754 \mu \mathrm{g} / \mathrm{mL}$, and the limits of quantitation were $0.806-2.420 \mu \mathrm{gmL}^{-1}$ for all drugs. The method was successfully applied for the determination of these drugs in their pharmaceutical preparations.
\end{abstract}

Keywords: Amino medicines, Rhodamine 6G, Ion-pair complexes, Spectrofluorimetry

\section{Introduction}

Nitrogen is a constituent of every major pharmacological drug class, approximately $42 \%$ of drugs and drug candidates contain amine functional groups [1], such as antibiotics, nonsteroidal anti-inflammatory, antiemetic, $\mathrm{H}_{2}$ receptor antagonist, beta adrenoceptor drugs, and others.

DIC, chemically named as 2-[(2,6dichlorophenyl)aminophenyl]acetate which decreases inflammation and pain, is a drug. It is a nonsteroidal anti-inflammatory drug used to treat pains and aches, as well as joint, muscle, and bone disorders. These involve osteoarthritis, rheumatoid arthritis, gout sprains, ligaments, muscle strains, back pain, spondylitis that causes inflammation of the spine, toothaches, and migraines, and other sections of the body [2,3].
DOM malate, chemically named as 5Chloro-1-(1-[3-(2-oxo-2,3-dihydro-1 H-benzo [d] imidazol- 1-yl)propyl]piperidin-4-yl)- $1 \mathrm{H}$ benzo[ $d]$ imidazol-2(3H)-one (II) is also called Motilium [4]. It is an antiemetic drug used as an "anti-vomiting" drug for vomiting and nausea caused by diseases of the digestive tract, especially those that appear as side effects of other drug treatments, especially anti-cancer drugs or radiation therapy [5], and it is also used for anti-dopamine treatments for Parkinson's disease [6]. FAM, chemically named as 3-[(\{2[(diaminomethylidene)amino]-1,3 - thiazol - 4 -yl\}methyl)sulfanyl] $-N$-sulfamoylpropanimidamid (III) is one of the medicines used to treat peptic ulcers, as it is considered a type II antihistamine $\left(\mathrm{H}_{2}\right.$-receptor blockers $)$ that inhibits the excessive secretion of stomach 
acid, eliminating heartburn especially in the stomach and esophagus, and speeding up the healing of ulcers [7-9]. PRO, chemically named as $(R S)-1-(1-$ methylethylamino)-3-(1naphthyloxy)propan-2-ol (IV) known since 1965, was the first beta-blocker in common use (Fig.1). PRO is beta adrenoceptor drug used to treat hypertension, angina pectoris, and arrhythmia. This drug is also effective in returning a fast heartbeat to its balanced rate and other symptoms caused by hyperthyroidism (Hyperthyroidism) and reducing heart rate, sweating, and trembling caused by severe anxiety. used to prevent migraine attacks [10].
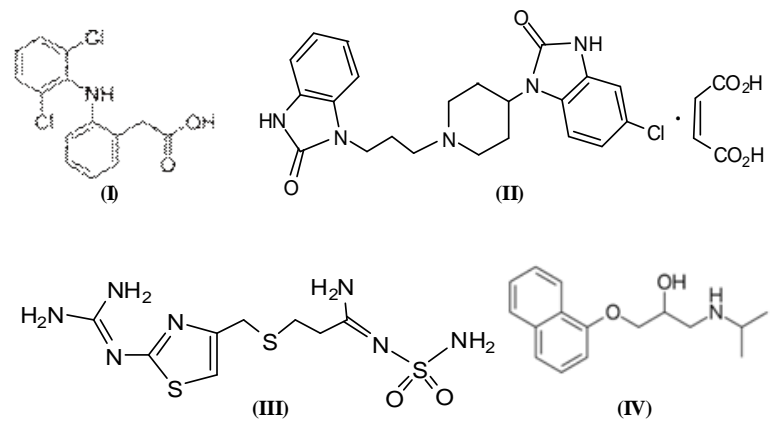

Figure 1. Structure of DIC (I), DOM (II), FAM (III) and PRO (IV)

Several analytical techniques have been described for the determination of the above drugs in their pure form and pharmaceutical formulations. These include HPLC [11-18], spectrophotometric [19-28], conductometric [29], and electrochemical methods [30-33] were described for the determination of these drugs. Few spectrofluorimetric methods have been reported in the literature for the determination of the studied drugs. These methods are either direct determination, depending on the measurement of the fluorescence intensity of the ion-pair complexes, or indirect determination by measurement of the quenching fluorescence of the dye through the formation of ion-pair complexes with these drugs, such as 7-fluoro-4-nitrobenzo-2-oxa- 1,3-diazole (NBD-Cl) [34], $\alpha$-cyclodextrin [35] for DIC, 9, 10-phenanthraquinone [36] for FAM and eosin Y [37] for PRO. R-6G is one of the most widely used dyes in dye laser and fluorescence tracer. Aqueous R-6G solutions are interesting when the dye is used as a fluorescence tracer [38]. It was used for indirect determination of some medicines depending on the addition of an excess amount of oxidizing agent and the unreacted oxidizing agent such as $\mathrm{N}$-bromosuccinimide, ceric sulphate $[39,40]$, and bromate bromide [41] that are decreased the signal of R-6G, which are directly proportional to the concentration of medicines. However, some of these methods suffer from one or more disadvantages such as expensive instrumentation, time-consuming, tedious extraction procedures, and low sensitivity. The present paper reports a simple spectrofluorimetric determination of some $\mathrm{N}$-containing drugs based on their quenching the fluorescent intensity of rhodamine $6 \mathrm{G}$ dye.

\section{Materials and Methods Instrumentation}

RF-5301 PC- Spectrofluorophotometer equipped with xenon lamp and $1 \mathrm{~cm}$ quartz cell was used. Philips PW 94 instrument supplied with CE 10-12 pH electrode was used for $\mathrm{pH}$ measurements. An electronic balance of D0001.A\&D Company Limited model was used for weighing.

\section{Chemical and Reagents}

All reagents and solvents were of analytical reagent grade provided by Fluka and $\mathrm{BDH}$ companies. R-6G was prepared in a concentration of $50 \mu \mathrm{gmL}^{-1}$ by dissolving 0.01 $\mathrm{g}$ in distilled water, and the volume was completed to $200 \mathrm{~mL}$ with distilled water in a volumetric flask. Acetate buffer solution (pH3.5) was prepared by dissolving $16.02 \mathrm{~g}$ of 
sodium acetate in $300 \mathrm{~mL}$ of distilled water. Then the $\mathrm{pH}$ was adjusted with acetic acid to 3.5 and complete the volume to $1 \mathrm{~L}$ with distilled water. Phthalate Buffer solution (pH6) was prepared by mixing $50 \mathrm{~mL}$ of 0.2 $\mathrm{M}$ potassium hydrogen phthalate with 45.4 $\mathrm{mL}$ of $0.2 \mathrm{M}$ sodium hydroxide, and volume completed to $200 \mathrm{~mL}$ with distilled water in a volumetric flask. The $\mathrm{pH}$ values were adjusted by the $\mathrm{pH}$ meter.

DIC and PRO were prepared in a concentration of $100 \mu \mathrm{gmL}^{-1}$ by dissolving $0.01 \mathrm{~g}$ of each drug in distilled water and complete the volume to $100 \mathrm{~mL}$ in a volumetric flask with distilled water. DOM and FAM were prepared in a concentration of $100 \mu \mathrm{gmL}^{-1}$ by dissolving $0.01 \mathrm{~g}$ of each drug in wormed distilled water with mixing, then cooled and completed the volume to 100 $\mathrm{mL}$ in a volumetric flask with distilled water. All the solutions were kept in the refrigerator.

\section{Procedure}

Aliquots of working stock solutions containing DIC, DOM, FAM, and PRO were added separately into $10 \mathrm{~mL}$ volumetric flasks containing $20 \mu \mathrm{gmL}^{-1} \mathrm{R}-6 \mathrm{G}$ in addition to 1.5 $\mathrm{mL}$ acetate buffer solution of $\mathrm{pH} 3.5$ for DIC, FAM, and $2 \mathrm{~mL}$ for PRO and containing $2 \mathrm{~mL}$ of phthalate buffer solution of $\mathrm{pH} 6$ for DOM. The volumes were completed to the mark with distilled water, and the fluorescence intensity of solutions was measured at $\lambda \mathrm{em}$ $552 \mathrm{~nm}$ after excitation at $\lambda$ ex $402 \mathrm{~nm}$ against a blank solution. The fluorescence intensity $(\Delta \mathrm{F})$ was plotted against the concentration of drugs in the final volume.

\section{Analysis of Pharmaceuticals DIC sodium, PRO, DOM and FAM tablets}

From each pharmaceutical form, 10 tablets of Voltaren (containing $100 \mathrm{mg}$ DIC sodium), 7 tablets of Inderal (containing 40 mg PRO), 10 tablets of Dompy (containing 10 mg DOM malate), and 10 tablets of Gastrofam (containing $40 \mathrm{mg}$ FAM). Each sample was ground and mixed well.Then accurately weighed equivalent to one tablet for each formulation which was dissolved in a few drops of ethanol to increase the solubility and completed with distilled water. The solutions were filtered through a Whatman no. 42 filter paper and completed to the suitable volumes with distilled water in volumetric flasks separately. Aliquots of each solution containing the amount within the corresponding calibration curve were analyzed as cited in the recommended procedure.

\section{DIC sodium ampule}

Three pharmaceutical ampoules (Voltaren), each one contain $75 \mathrm{mg} / 3 \mathrm{~mL}$ DIC sodium, were mixed well, then $1.0 \mathrm{~mL}$ volume of content was diluted to $100 \mathrm{~mL}$ with distilled water to obtain $250 \mu \mathrm{gmL}^{-1}$. This solution was further diluted, and the concentration of the drug per ampoule was determined using its respective calibration graph constructed for pure form by following the recommended procedure.

\section{Results and Discussion}

Methods for estimating the fluorescence of ion-pair complexes generally depend on the quenching process. In ion-pair, if one of the ions is a fluorophore, the counter ion behaves as a quenching agent. With a certain concentration range, the fluorescence decreases in proportion to the analyte concentration [42]. This study aims to develop a sensitive spectrofluorimetric method for the assay of DIC, PRO, FAM, and DOM drugs in their pure forms and dosage forms. In this study, it was found that R-6G dye has fluorescent emission at $552 \mathrm{~nm}$ after excitation at $402 \mathrm{~nm}$ (Fig. 2). When the above drugs are added to the dye, a significant quenching of fluorescence intensity has been 
observed, and increased in an acidic medium has occurred. This may be due to the formation of non-fluorescent ion-pair complexes by electrostatic attraction between medicines and the dye [37,43-45]. The decrease of fluorescence intensity of R$6 \mathrm{G}$ is found to be a linear function of $\mathrm{N}$ containing medicines concentrations in water solution.

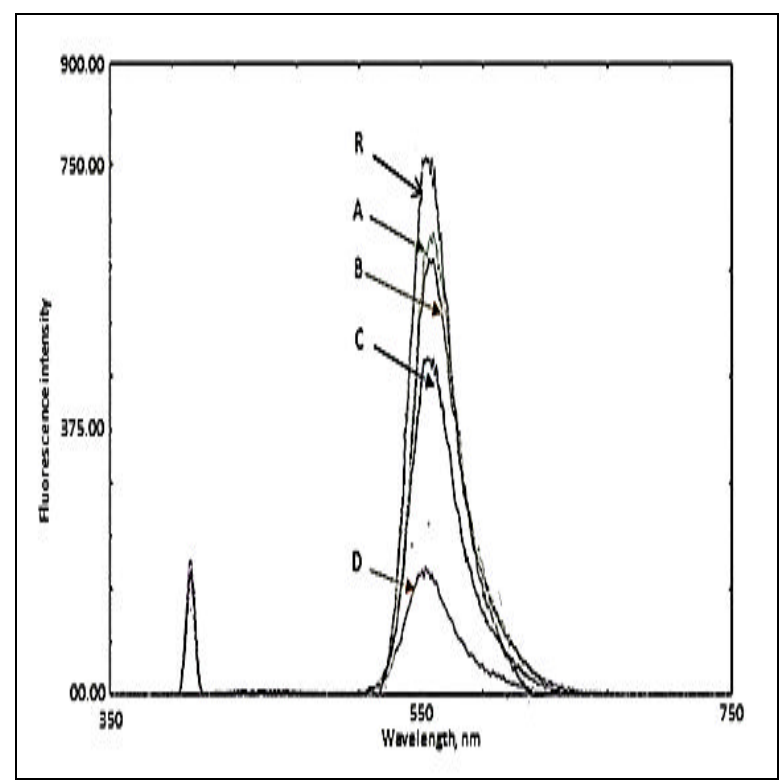

Figure 2. Effect of (A) $1 \mu \mathrm{gmL}^{-1}$ PRO, (B) $3 \mu \mathrm{gmL}^{-1} \mathrm{DIC}$, (C) 14 $\mu \mathrm{gmL}^{-1}$ FAM and (D) $15.5 \mu \mathrm{gmL}^{-1} \mathrm{DOM}$ on the quenching of $\circledast 20$ $\mu \mathrm{gmL}^{-1} \mathbf{R - 6 G}$ dye

However, the method is dependent on the measurement of the quenching of fluorescein dye which is proportional to the concentration of studied medicines.

\section{Optimization of Conditions}

Various experimental factors affecting the fluorescence intensity of the complexes have been studied and optimized, such factors were changed individually while others were kept constant. These factors include a selection of R-6G dye concentration, $\mathrm{pH}$, buffer solution, temperature, and solvent.

\section{Selection of R-6G Concentration}

To select the optimum concentration of R-6G dye for the determination of the intended medicines, a calibration graph was constructed by plotting absorbance versus aliquots of $50 \mu \mathrm{gmL}^{-1}$ of dye in a set of $10 \mathrm{~mL}$ calibrated flasks and diluted to the mark with distilled water. The emission of fluorescence intensity was measured after $10 \mathrm{~min}$ at $552 \mathrm{~nm}$ after excitation at $402 \mathrm{~nm}$.

The linearity was found in the range of $0.1-20.0 \mu \mathrm{gmL}^{-1}$ (Fig. 3). However, $20 \mu \mathrm{gmL}^{-1}$ of R-6G dye was selected for analysis of the drugs in this study.

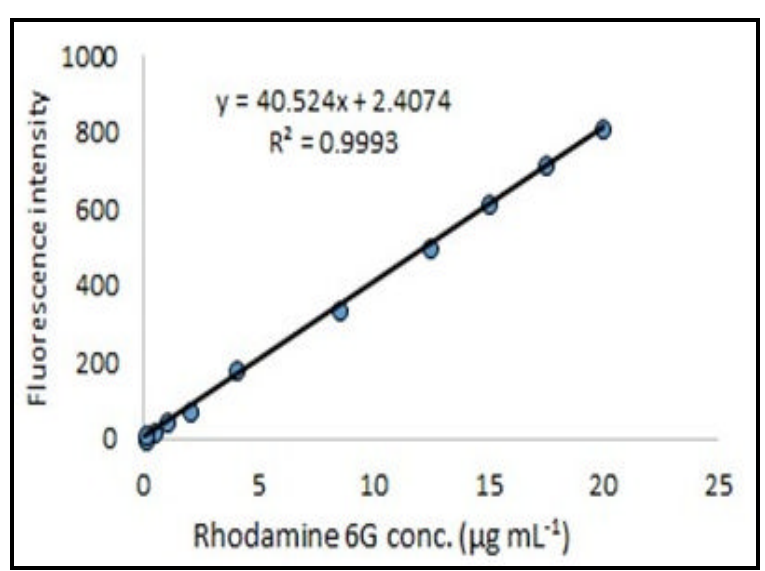

Figure 3. Calibration Graph of R-6G day

\section{Effect of pH and Buffers}

The effect of changing $\mathrm{pH}$ on the fluorescence intensity for the complexes was studied by the addition of different buffer types with different $\mathrm{pHs}$ such as acetate, phthalate, and citrate of $\mathrm{pH}$ ranges 3-6 were prepared and examined. As seen in Table 1, acetate buffer of $\mathrm{pH} 3.25$ gave maximum $\Delta \mathrm{F}$ for DIC, PRO and FAM drugs, whereas phthalate buffer of $\mathrm{pH} 6$ for DOM drug, with volumes of $2,1.5,1.5$, and $2 \mathrm{~mL}$, respectively (Table 2 ), which are chosen as the optimum throughout the study. 
Table 1. Effect of $\mathrm{pH}$ on the intensity $(\Delta \mathrm{F})$ of drugs.

\begin{tabular}{|c|c|c|c|c|c|}
\hline \multirow{2}{*}{$\begin{array}{c}\begin{array}{c}\text { Type of } \\
\text { buffer } \\
\text { solution }\end{array} \\
\end{array}$} & \multirow{2}{*}{ pH } & \multicolumn{4}{|c|}{$\Delta F$} \\
\hline & & PRO & FAM & DOM & DIC \\
\hline \multirow{9}{*}{$\begin{array}{l}\text { Acetate } \\
\text { buffer }\end{array}$} & 3.0 & 121 & 49 & 37 & 220 \\
\hline & 3.25 & 125 & 52 & 42 & 222 \\
\hline & 3.5 & 122 & 53 & 38 & 199 \\
\hline & 4.0 & 120 & 56 & 38 & 170 \\
\hline & 4.5 & 115 & 56 & 32 & 171 \\
\hline & 5.0 & 110 & 58 & 30 & 175 \\
\hline & 5.25 & 90 & 59 & 27 & 175 \\
\hline & 5.5 & 85 & 64 & 27 & 180 \\
\hline & 6.0 & 77 & 73 & 22 & 174 \\
\hline \multirow{9}{*}{$\begin{array}{l}\text { Phthalate } \\
\text { buffer }\end{array}$} & 3.0 & 121 & 50 & 35 & 212 \\
\hline & 3.25 & 121 & 52 & 35 & 218 \\
\hline & 3.5 & 121 & 55 & 33 & 216 \\
\hline & 4.0 & 117 & 57 & 30 & 200 \\
\hline & 4.5 & 107 & 60 & 28 & 180 \\
\hline & 5.0 & 100 & 60 & 27 & 188 \\
\hline & 5.25 & 100 & 61 & 27 & 189 \\
\hline & 5.5 & 87 & 69 & 25 & 189 \\
\hline & 6.0 & 80 & 75 & 22 & 187 \\
\hline \multirow{9}{*}{$\begin{array}{l}\text { Citrate } \\
\text { buffer }\end{array}$} & 3.0 & 110 & 40 & 33 & 200 \\
\hline & 3.25 & 112 & 40 & 39 & 190 \\
\hline & 3.5 & 100 & 39 & 35 & 187 \\
\hline & 4.0 & 99 & 40 & 35 & 178 \\
\hline & 4.5 & 99 & 49 & 33 & 175 \\
\hline & 5.0 & 99 & 49 & 30 & 166 \\
\hline & 5.25 & 92 & 54 & 32 & 162 \\
\hline & 5.5 & 87 & 57 & 28 & 162 \\
\hline & 6.0 & 80 & 69 & 28 & 160 \\
\hline
\end{tabular}

Table 2. Effect of buffer solution volume on the intensity $(\Delta \mathrm{F})$ of drugs.

\begin{tabular}{|c|c|c|c|c|c|c|}
\hline \multirow[b]{2}{*}{ Buffer } & \multirow{2}{*}{$\begin{array}{c}\text { Volume } \\
(\mathrm{mL})\end{array}$} & \multicolumn{3}{|c|}{$\Delta \mathbf{F}$} & \multirow{2}{*}{$\begin{array}{c}\text { Buffer } \\
\text { sol ution }\end{array}$} & \multirow{2}{*}{$\frac{\Delta \mathrm{F}}{\mathrm{DOM}}$} \\
\hline & & $\overline{\text { DIC }}$ & FAM & PRO & & \\
\hline \multirow{10}{*}{ 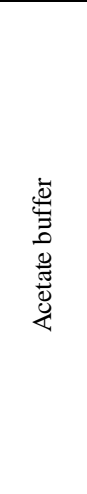 } & 0.25 & 111 & 30 & 220 & \multirow{10}{*}{ 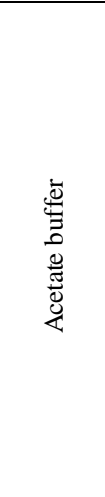 } & 61 \\
\hline & 0.50 & 115 & 33 & 222 & & 64 \\
\hline & 0.75 & 120 & 37 & 199 & & 70 \\
\hline & 1.00 & 125 & 42 & 222 & & 75 \\
\hline & 1.25 & 129 & 46 & 130 & & 79 \\
\hline & 1.50 & 134 & 50 & 240 & & 83 \\
\hline & 1.75 & 137 & 50 & 240 & & 87 \\
\hline & 2.00 & 140 & 50 & 237 & & 90 \\
\hline & 2.25 & 138 & 50 & 237 & & 90 \\
\hline & 2.50 & 138 & 50 & 237 & & 89 \\
\hline
\end{tabular}

\section{Effect of temperature and time}

The temperature effect ranging from $28^{\circ} \mathrm{C}$ (R.T) to $40^{\circ} \mathrm{C}$ and time on the quenching the fluorescence intensity of R-6G for the studied medicines, in the presence of suitable buffer solution, were studied. It was found that the fluorescence intensity $(\Delta \mathrm{F})$ was increased after $5 \mathrm{~min}$ at room temperature and remained stable for more than $200 \mathrm{~min}$ (Fig. 4). Whereas decreasing in intensity was found at $40^{\circ} \mathrm{C}$. However, a standing time of 5 min was chosen for all drugs.

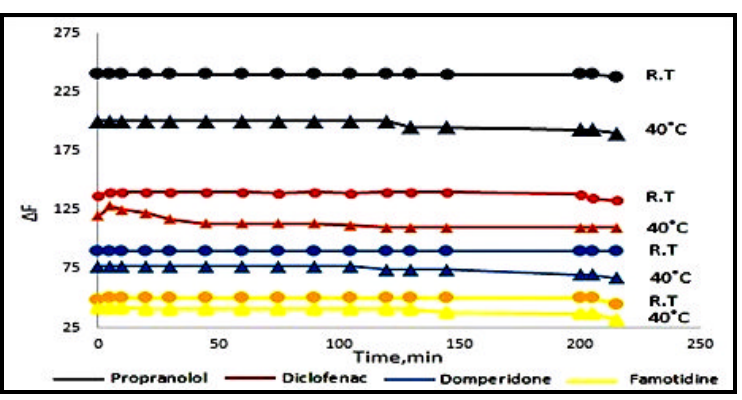

Figure 4. Effect of the temperature and the developing time on the intensity $(\Delta F)$ of medicines

\section{Effect of diluting solvents}

Dilution effects with water and other different organic solvents, such as acetone, methanol, ethanol, dimethylformamide (DMF), and dimethyl sulphoxide (DMSO), were examined on the fluorescence intensity. The results indicated that water was the best solvent, whereas the organic solvents decreased the fluorescence of R-6G dye (Fig. 5). Therefore, water was recommended as a diluting solvent.

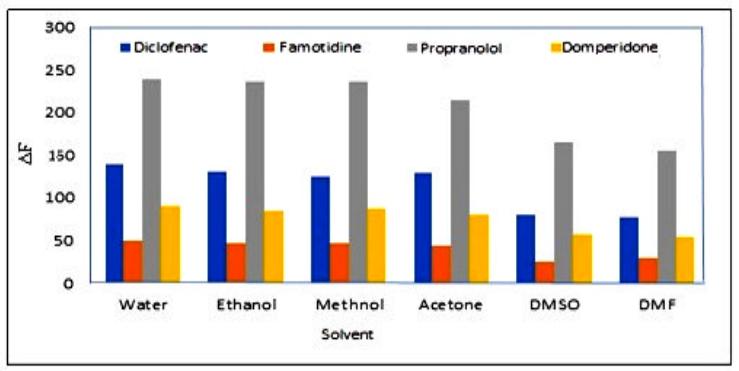

Figure 5. Effect of solvents on the intensity $(\Delta F)$ of drugs 


\section{Effect of surfactants}

Different surfactants such as triton $\mathrm{x}$ 100 (Tr-100), tween 80 (Tw-80), sodium dodecyl sulphate (SDS), and cetylpyridinium chloride (CPC) were examined. As shown in Fig. 6, The results indicated decreased fluorescence intensity $(\Delta \mathrm{F})$. Therefore the surfactants were omitted in this study.

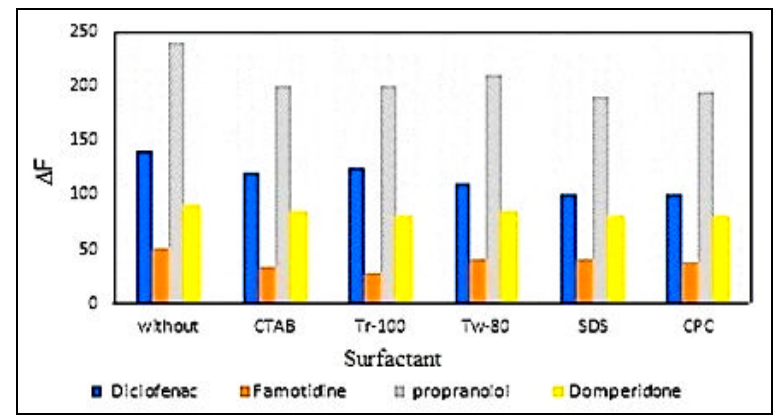

Figure 6. Effect of surfactant on the fluorescence intensity $(\Delta F)$ of drugs

\section{Effect of sequence addition}

Four sets of drug solutions were prepared but with a different order of additions. Under the previous optimum conditions, the sample solutions were measured at $\lambda \mathrm{ex}=402 \mathrm{~nm}$ and $\lambda \mathrm{em}=552 \mathrm{~nm}$ for DIC, DOM, FAM, and PRO against their corresponding blank solution, respectively. As demonstrated in Figure 7 show that the addition of R-6G followed by buffer solution and the drug was gave maximum intensity $(\Delta \mathrm{F})$ and recommended in the general procedure.

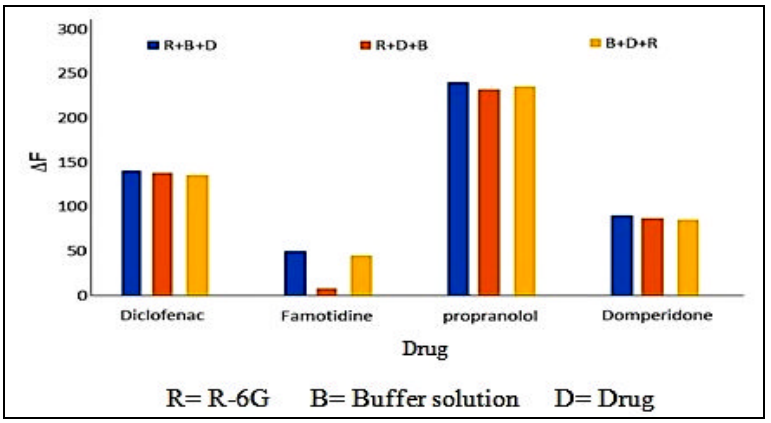

Figure 7. Effect of a sequence of additions

\section{Effect of pharmaceutical excipients}

The effect of common excipients used in pharmaceutical formulations such as starch, glucose, lactose, sucrose and sodium chloride, Mg-stearate, sodium sulphate, and potassium chloride were investigated for all studied drugs. The results cited in Table 3 indicated no interference could be observed within a 200 fold excess of excipient present in the proposed method.

Table 3. Effect of excipients on the recovery \% of drugs.

\begin{tabular}{|c|c|c|c|c|c|c|c|c|}
\hline \multirow{3}{*}{$\begin{array}{c}\text { Excip } \\
\text { ient }\end{array}$} & \multicolumn{8}{|c|}{ Recovery \% of $2.5 \mu \mathrm{gmL}^{-1}$} \\
\hline & \multicolumn{2}{|c|}{ DIC } & \multicolumn{2}{|c|}{ DOM } & \multicolumn{2}{|c|}{ FAM } & \multicolumn{2}{|c|}{ PRO } \\
\hline & 500 & 100 & 500 & 100 & 500 & 100 & 500 & 100 \\
\hline Starch & 99.21 & 94.54 & 97.54 & 95.01 & 95.92 & 95.54 & 95.43 & 95.69 \\
\hline Glucose & 98.89 & 96.10 & 98.25 & 96.22 & 98.97 & 95.90 & 98.44 & 97.41 \\
\hline Lactose & 100.50 & 96.95 & 99.10 & 94.95 & 97.92 & 97.20 & 96.17 & 95.98 \\
\hline Sucrose & 98.94 & 97.58 & 97.99 & 9557 & 97.72 & 97.24 & 95.44 & 96.31 \\
\hline $\mathrm{KCl}$ & 99.32 & 95.02 & 98.00 & 9536 & 98.99 & 94.25 & 98.54 & 97.00 \\
\hline $\mathrm{NaCl}$ & 100.95 & 95.23 & 96.95 & 96.11 & 100.89 & 97.39 & 99.99 & 97.01 \\
\hline $\mathrm{Na}_{2} \mathrm{SO}_{4}$ & 99.01 & 95.23 & 99.00 & 97.58 & 95.00 & 95.02 & 95.85 & 95.05 \\
\hline $\begin{array}{l}\text { Mg- } \\
\text { stearate }\end{array}$ & 99.01 & 95.32 & 99.23 & 95.65 & 99.21 & 97.32 & 99.91 & 95.37 \\
\hline
\end{tabular}

\section{Calibration graphs and analytical results}

Calibration graphs were plotted under the optimum experimental conditions constructed to the difference in fluorescence intensity $(\Delta \mathrm{F})$ as a function of the corresponding DIC, PRO, FAM, and DOM concentrations in $\mu \mathrm{g} \mathrm{mL}{ }^{-1}$, where calibration graphs showed excellent linearity in the ranges $0.1-9.0,0.05-5.0,0.1-14.0$ and $0.05-15 \mu \mathrm{g} \mathrm{mL} \mathrm{m}^{-1}$ for above medicines, respectively (Fig. 8). The characteristics of the calibration graphs are summarized in (Table 4). 
Table 4. The characteristics of the calibrationgraphs.

\begin{tabular}{lcccc}
\hline Parameters & PRO & DIC & DOM & FAM \\
\hline $\begin{array}{l}\text { Linearity range } \\
\left(\mu \mathrm{gmL}^{-1}\right)\end{array}$ & $0.05-5.0$ & $0.1-9.0$ & $0.05-15$ & $0.1-14.0$ \\
Slope & 120.81 & 68.458 & 40.154 & 24.209 \\
Intercept & 3.895 & 0.3213 & 4.6381 & 1.8015 \\
$\mathrm{R}^{2}$ & 0.9991 & 0.9996 & 0.9992 & 0.9994 \\
\hline
\end{tabular}

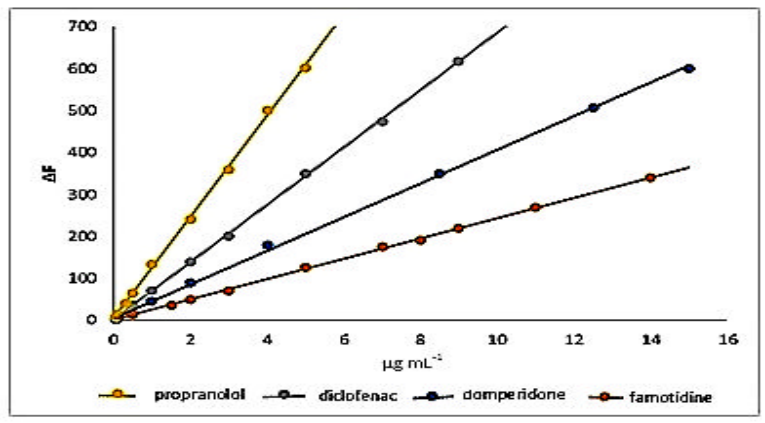

Figure 8. Calibration graphs for the studied drugs

\section{Accuracy and precision}

The accuracy was examined using three replicate analysis for each of three different concentrations within the calibration graph of each drug. The results, cited in Table 5, show the agreement between the true and measured values indicating good accuracy of the suggested method. The relative standard deviation (RSD) values were calculated and found to be $\leq 2.56$ for all the studied drugs indicating good reliability and repeatability of the method.

Table 5. Accuracy and precision of the method.

\begin{tabular}{ccccc}
\hline Drug & $\begin{array}{c}\text { Amount } \\
\text { added } \\
\left(\boldsymbol{\mu g} \mathbf{~ m L}^{-1}\right)\end{array}$ & $\begin{array}{c}\text { Recovery* } \\
\%\end{array}$ & $\begin{array}{c}\text { Average } \\
\text { recovery \% }\end{array}$ & RSD \\
\hline \multirow{3}{*}{ DIC } & 2 & 104.21 & & 1.19 \\
& 5 & 100.70 & 100.97 & 2.33 \\
& 7 & 98.01 & & 0.79 \\
\hline \multirow{2}{*}{ DOM } & 3 & 100.33 & & 0.73 \\
& 6 & 100.18 & 100.25 & 2.56 \\
& 9 & 100.26 & & 1.98 \\
\hline \multirow{2}{*}{ FAM } & 3 & 96.65 & & 1.02 \\
& 6 & 100.65 & 99.45 & 0.57 \\
& 9 & 101.06 & & 1.32 \\
\hline \multirow{3}{*}{ PRO } & 1.5 & 100.49 & & 1.1 \\
& 3 & 97.70 & 99.48 & 1.0 \\
*Average of five determinations & 100.26 & & 1.2 \\
\hline
\end{tabular}

\section{Method validation}

To check the validity of the proposed method, it was applied successfully for the determination of DIC, DOM, FAM, and PRO in their commercial dosage forms as injection and tablets. The obtained values of recovery $\%$ are cited in Table 6 which indicate good accuracy and showed no serious interferences with the excipients. The results obtained by the suggested method were statistically compared with those of official methods [46], which are dependent on potentiometric titrations for their pure forms. By applying t-test for accuracy and F-test for precision at 95\% confidence level with four degrees of freedom. The experimental values for $\mathrm{t}$ and $\mathrm{F}$ tests, as seen in Table 6, did not exceed the theoretical values $(t=2.78, F=6.39)$. This confirmed that there are no significant differences between the proposed method with the official method.

Table 6. Determination of DIC, DOM, FAM and PRO in their dosage forms by the proposed method.

\begin{tabular}{lcccc}
\hline \multirow{2}{*}{$\begin{array}{l}\text { Pharmaceutical } \\
\text { preparations }\end{array}$} & \multicolumn{4}{c}{ Recovery $^{\mathbf{a}}(\boldsymbol{\%})$} \\
\cline { 2 - 5 } & $\begin{array}{c}\text { Present } \\
\text { method }\end{array}$ & $\begin{array}{c}\text { Standard } \\
\text { method }^{\mathbf{3 7})}\end{array}$ & $\mathbf{t}_{\text {exp. }}$ & $\mathbf{F}_{\text {test }}$ \\
\hline Voltaren injection & 98.37 & 99.41 & 1.20 & 1.62 \\
Dompy tablet & 100.09 & 99.71 & 1.21 & 1.51 \\
Gastrofam tablet & 99.21 & 98.17 & 1.73 & 1.47 \\
Inderal tablet & 98.74 & 99.25 & 0.98 & 1.01 \\
\hline
\end{tabular}

\section{Conclusion}

A new simple, accurate and sensitive spectrofluorimetric method has been proposed for the determination of DIC, DOM, FAM, and PRO drugs in bulk and their dosage forms. The method is dependent on the measurement of the quenching fluorescence intensity of R-6G dye through the formation of ion-pair complexes between the studied drugs and the dye. The proposed method is free from interference by common additives and excipients and does not require any pretreatment or extraction steps. 


\section{Conflict of interest}

The authors declare that there is no conflict of interest.

\section{References}

1. S. D. Roughley and A. M. Jordan, $J$. Med. Chem., 54 (2011) 3451. doi:10.1021/jm200187y. PMID 21504168

2. H. Brittain, Analytical Profiles of Drug Substances and Excipients, 1 Ed. (1998) 19, 123, Academic Press Inc, NY, USA. https://doi.org/10.1016/s00995428(08)x6033-2

3. M. M. Sein, M. Zedda, J. Tuerk, T. C. Schmidt, A. Golloch and C. V. Sonntag, Environ. Sci. Technol., 42 (2008) 6656. doi.org/10.1016/j.msec.2012.04.066

4. D. Silvers, M. Kipnes, V. B. David, P. Eamonn, M. M. Quigley and R. McCallum, Clin. Ther., 20 (1998) 438. doi.org/10.1016/S0149-2918(98)80054-4

5. G. Seema, A. S. Atul, S. J. Yogini and J. S. Sanjay, J. Planar Chromatogr.-Mod. TLC, 19 (2006) 302.

doi: 10.1556/JPC.19.2006.4.8

6. B. G. Katzung, Basic \& Clinical Pharmacology, 14 Ed., Delhi, Mc-Graw Hill Companies, Inc., India (2018)1097.

7. N. Rami Reddy, K. Prabhavathi, Y. V. Bhaskar Reddy and I. E. Chakravarthy, Ind. J. Pharm. Sci., 68 (2006) 645. doi: 10.4103/0250-474X.29637

8. H. A Mohanmed, Bull. Pharm. Sci., Assiut. Univ., 23 (2000) 157. doi: $10.21608 / \mathrm{bfsa} 2000.66402$

9. I. E. Chakravarthy, N. R. Reddy, K. Prabhavathi and Y. V. B. Reddy, Ind. J. Pharm. Sci., 68 (2006) 645. doi.org/10.4103/0250-474x.29637

10. O. B. Garfein, Ther. Drug Monit., 4 (1982) 1.

doi:10.1097/00007691-198204000-00001

11. B. T. Alquadeib, Saudi Pharm. J., 27 (2019) 66. doi: $10.1016 /$ j.jpss.2018.07.020
12. S. D. Labhade, S. R. Chaudhari and R. B. Saudagar, J. Anal. Pharm. Res., 7 (2018) 244. doi: 10.15406/japlr.2018.07.00233

13. V. Mistry and R. Mishra, Asian $J$. Pharm. Clin. Res., 11 (2018) 125. doi: 10.22159/ajpcr.2018.v11i10.26132

14. A. Khan, Z. Iqbal, I. Khadra, L. Ahmad, A. Khan, M. I. Khan, Z. Ullah and Ismail, J. Pharm. Biomed. Anal., 20 (2016) 6. doi: 10.1016/j.jpba.2015.12.036

15. M. Hanif, N. Nazer, V. Chaurasiya and U. Zia, Trop. J. Pharm. Res., 15 (2016) 605. doi:10.4314/tjpr.v15i3.24

16. A. Nita, D. M. Tit, L. Copolovici, C. E. M. Frunzulica, D. M. Copolovici, S. Bungau and C. Iovan, Rev. Chim. (Bucharest), 69 (2018) 297. doi: 10.37358/RC.18.2.6093

17. H. A. Al Shaker, N. A. Qinna, H. Al Hroub, M. M. H. Al Omari and A. A. Badwan, Acta Chromatogr., 30 (2018) 147. doi.org/10.1556/1326.2017.00018

18. M. C. Filho, L. Rocha, N. C. B. Duarte, L. L. Sa-Barreto, Biomed. Chromatogr., 35 (2021) e4987. https://doi.org/10.1002/bmc.4987

19. I. C. Uzochukwu and S. O Nzegbunam, Trop. J. Pharm. Res., 14 (2015) 519. http://dx.doi.org/10.4314/tjpr.v14i3.22

20. F. Fallah, M. R. Shishehbore and A. Sheiban, Orient. J. Chem., 32 (2016) 727. http://dx.doi.org/10.13005/ojc/320181

21. M. S. Chohan, R. E. E. Elgorashe, A. A. Balgoname, M. Attimarad, N. S. Harsha, K. N. Venugopala, A. B. Nair and S. Pottathil, Ind. J. Pharm. Educ. Res., 53 (2019) 166. doi:10.5530/ijper.54.1.20

22. K. L. Bhaskar, D. Sri Lakshmi, G. Sumalatha, G. Suji and K. A.T. Kumar, Res. J. Pharm. Techn., 13 (2020) 6050. 
doi:10.5958/0974-360X.2020.01054.9

23. S. Rao, T. V. Kumar and E. Praveen, $J$. Appl. Chem., 6 (2013) 52. doi: 10.9790/5736-0615260

24. J. Shah, M. R. Jan and M. T. Shah, Bangladesh Pharm. J., 17 (2015) 25. doi: 10.3329/bpj.v17i1.22310

25. S. A. E. Abass, M. Walash and F. Ibrahim, Pharm. Anal. Acta, 7 (2016) 2. doi: 10.4172/2153-2435.1000476

26. D. K. Sharma, J. Singh and P. Raj, Int. J. Pharm. Pharm. Sci., 10 (2018) 107. doi.org/10.22159/ijpps.2018v10i2.23682

27. K. N. Prashanth and K. Basavaiah, Proc. Nat. Acad. Sci., India, Sect. A Phys. Sci., 84 (2014) 27.

doi: 10.1007/s40010-013-0106-4

28. G. D. Fonsêca, A.S. A. de Medeiros and E. G. do Nascimento, J. Anal. Chem., 75 (2020) 184. doi:10.1134/S1061934820020057

29. E. R. Sartori, N. V. Barbosa, R. C. Faria and O. Fatibello-Filho, Ecl. Quím., São Paulo, 36 (2011) 110.

https://doi.org/10.1590/S010046702011000100008

30. M. M. Eteya, G. H. Rounaghi and B. Deiminiat, Microchem. J., 144 (2019) 254.

https://doi.org/10.1016/j.microc.2018.09.009

31. T. Wahdan and N. Abd El-Ghany, Il Farmaco, 60 (2005) 830. https://doi.org/10.1016/i.farmac.2005.07.001

32. I. David, D. E. Popa, A. A. Calin, M. Buleandra and E. E. Iorgulescu, Turk. J. Chem., 40 (2016) 125. doi: 10.3906/kim-1504-42

33. A. Santhy, S. Beena, U. S. K. Namboothiri S. Anupriya and C. V. Sreeranjini, IOP Conf. Ser.: Mater. Sci. Eng., 872 (2020) 1. doi:10.1088/1757-899X/872/1/012125

34. S. T. Ulu, J. Food Drug Anal., 19, (2011) 94. https://doi.org/10.38212/2224$\underline{6614.2202}$
35. J. A. Arancibia, M. A. Boldrini, G. M. Escandar, Talanta, 52 (2000) 261. doi: 10.1016/s0039-9140(00)00338-6

36. M. I. Walash, A. El-Brashy, N. ElEnany, M. E. Kamel, J. Fluoresc., 19 (2009) 333. doi 10.1007/s10895-008-0421-3

37. S. M Derayea, M. A Omar, M. A. Abdel-Lateef and A. I. Hassan, Open Chem., 14 (2016) 258. doi: 10.1515/chem-2016-0024

38. F. M. Zehentbauer, C. Moretto, R. Stephen, T. Thevar, J. R. Gilchrist, D. Pokrajac, K. L. Richard and J. Kiefer, Spectrochim. Acta Part A, 121 (2014) 147. doi: 10.1016/j.saa.2013.10.062

39. A. S. Amin, S. A. Shama, I. S. Ahmed, and E. A. Gouda, Anal. Lett., 35 (2002) 1851. doi:10.1081/AL-120013588

40. A. S. Amin and G. H. Ragab, Anal. Sci., 19 (2003) 747. doi10.2116/analsci.19.747

41. J. A. M. Pulgarín, A. A. Molina and P. F. López, Talanta, 68, 3 (2006) 586. https://doi.org/10.1016/j.talanta.2005.04.051

42. M. Florea and M. Ilie, Spectroscopic Analyses - Developments and Applications (InTech, Janeza Trdine 9, 51000, Rijeka, Croatia) Chapter 9, (2017) p.173. doi: 10.5772/intechopen.69778.

43. T. N. Al-Sabha, M. Y. Dhamra and T. S. Al-Ghabsha, Eur. Chem. Bull., 6 (2017) 336.

https://doi.org/10.17628/ecb.2017.6.336-342

44. K. C. Ramesh, B. G. Gowda, S. Jaldappagari and J. Keshavayya, J. Anal. Chem., 58 (2003) 933. https://doi.org/10.2116/analsci.18.671

45. H. Fael, A. A. Sakur, J. Fluoresc., 25 (2015) 1577. doi: 10.1007/s10895-015-1666-2

46. British pharmacopeia, CD-ROM, system simulation, the stationary office Ltd., London (2013). 